\title{
CORRIGENDUM
}

\section{Oncolytic adenovirus co-expressing IL-12 and IL-18 improves tumor-specific immunity via differentiation of T cells expressing IL-12R $\beta_{2}$ or IL-18R $\alpha$}

I-K Choi, J-S Lee, S-N Zhang, J Park, CH Sonn, K-M Lee and C-O Yun

Gene Therapy (2011) 18, 942; doi:10.1038/gt.2011.72; published online 31 March 2011

Correction to: Gene Therapy (2011) 18, 898-909; doi:10.1038/ The authors would like to apologise for this error. gt.2011.37; published online 31 March 2011

Since the online publication of this paper the authors have noticed that the order of authors is incorrect. The correct order is shown above. 